\title{
Morphologic and AFLP Analysis of Relationships between Tulip Species Tulipa biebersteiniana (Liliaceae)
}

\author{
N. A. Kutlunina ${ }^{a}$, M. A. Polezhaeva ${ }^{b}$, and M. V. Permyakova ${ }^{a}$ \\ ${ }^{a}$ Department of Botany, Yeltsin Ural Federal University, \\ Yekaterinburg, 620002 Russia \\ e-mail: natakutlunina@mail.ru \\ ${ }^{b}$ Institute of Plant and Animal Ecology, Ural Branch, \\ Russian Academy of Sciences, Yekaterinburg, 620144 Russia \\ e-mail:polezhaevam@mail.ru \\ Received June 21, 2012
}

\begin{abstract}
In populations of four species of tulips (Tulipa biebersteiniana, T. patens, T. scytica and T. riparia) from the Volgograd, Kurgansk, Orenburg, and Chelyabinsk regions and the Republic of Bashkortostan, genetic diversity was studied by means of morphological and AFLP analysis. A morphological analysis of seven quantitative and two qualitative criteria was carried out. Three selective EcoRI/MseI primer pairs allowed one to genotype 81 individuals from 13 tulip populations with 87 loci. The low level of variability by AFLP loci were revealed in all species, including T. biebersteiniana $\left(P=20.41 \%, U H_{\mathrm{e}}=0.075\right), T$. patens (26.97\%, 0.082), T. scytica $(27.53 \%, 0.086)$, and T. riparia $(27.72 \%, 0.096)$. According to the AMOVA results, the variability proportion that characterizes the differences between the four Tulip species was lower $\left(F_{\mathrm{CT}}=0.235\right)$ than between populations within species $\left(F_{\mathrm{ST}}=0.439\right)$. Tulipa patens is well differentiated by means of Nei's distances, coordination, and analysis in the STRUCTURE program. An analysis in the STRUCTURE revealed four genetic groups of tulips that are not completely in accordance with the analyzed species. This acknowledges the presence of complicated genetic process in the tulip population.
\end{abstract}

Keywords: Liliaceae, Tulipa biebersteiniana, T. patens, T. scytica, T. riparia, AFLP, genetic diversity DOI: $10.1134 / \mathrm{S} 1022795413040091$

\section{INTRODUCTION}

Representatives of Tulipa L. are decorative bulbous plants, which are bred all over the world and involve about 4000 breeds. Wild species of tulips account for the unique appearance of steppe and mountainous regions of Eurasia in early spring. Presently, there is no uniform position with respect to systematics of Tulipa. Indeed, the number of species defined by different authors varies from 40-55 [1, 2] to more than 100 [3]. The World Checklist for Tulipa [4] provides 418 taxons and 112 species. Based on an analysis of genome size, as well as by a series of other traits [5], the genus is divided in four subgenuses, i.e., Clusianae (Baker) Zonn., Tulipa, Eriostemones Raamsd. and Orithyia (D. Don) Baker. Representatives of the subgenus Eriostemones are characterized by small flowers with Eriostemones-type stamens and embryo sac. The subgenus Eriostemones is divided in three sections [3, 5]: Sylvestres (Baker) Baker, Biflores A.D. Hall ex Zonn. and Veldk. and Saxatiles (Baker) Baker. The Southern Urals are populated by one species that belongs to Biflores (T. biflora Pall.) and four species that belong to the subgenus Sylvestres (T. patens C. Agardh ex Schult. et Schult., T. biebersteiniana Schult. et Schult. f.,
T. scythica Klok. et Zoz. and T. riparia Knjas., Kulikov et Philippov) [6]. The first two species are acknowledged and the others, T. scythica and T. riparia, are often considered to be synonyms of $T$. biebersteiniana $[7,4]$. Conversely, some authors consider $T$. scythica and $T$. patens to be more closely related. These species are characterized by different color of flowers (T. patens has pink flowers and $T$. scythica has yellow flowers), but similar ontomorphogenesis, i.e., the absence vegetative reproduction and the formation of a substituting bulb of juvenile specimens under the bulb of the previous year, as a result of which a characteristic chain of bulbs remnants is formed. In the generative state, a substituting bulb is formed near the maternal one. Both species are characterized by a small size of generative stem and narrow leaves that are either oriented upwards or acutely curved. The similarity of ontomorphogenesis and habitus, as well as the ecological association with stony steppe slopes allowed Knyazev et al. [6] to suggest that $T$. scythica is related to $T$. patens rather than T. biebersteiniana. In the flora of the Lower Volga [8], $T$. scythica is considered to be a synonym of $T$. patens. However, it has been noted that both species may be involved in the polymorphous $T$. sylvestris. Outside of the Urals, the areals of $T$. scythica and T. patens are 


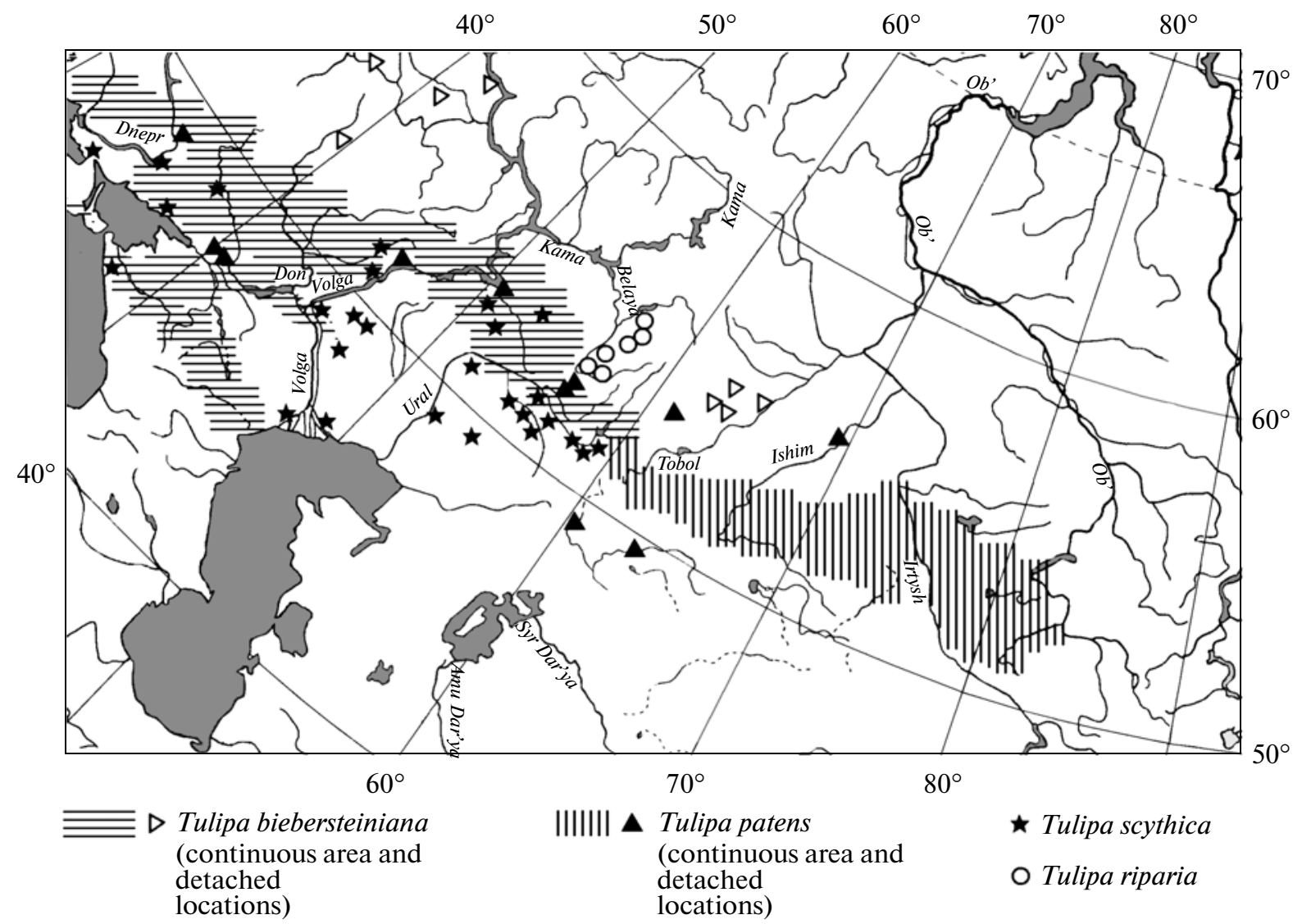

Fig. 1. Scheme of areals of studied species of tulips.

hardly intercrossed (Fig. 1). The T. patens is distributed in the steppe zone of Western Kazakhstan and Siberia up to Khakassia, and penetrates northern China. Indications for $T$. patens in Eastern Europe may be connected with mistakes in estimations or are represented by small isolated populations. T. scythica is distributed in the steppe regions of Eastern Europe. This is typical of the Orenburg region, south of the $52^{\circ} \mathrm{N}$; it penetrates northern Kazakhstan (Fig. 1).

Two other species, T. riparia and T. biebersteiniana, can reproduce vegetatively, forming plagiotropic stolons with a bulb at the end. The substituting bulb is not always formed near the maternal bulb. Therefore, chains of bulb remnants from previous years are not formed. T. biebersteiniana is typically characterized by yellow flowers. However, pink flowers are seldom found, including all over the areal [6]. The areal of $T$. biebersteiniana is quite wide. In the east, it reaches the Kurgan region. In the north, it reaches the south of the Moscow region (Fig. 1). It can be found under the forest canopy, in inundated populations, and in steppe regions in the places with lower relief. T. riparia was first described in 2001 [6]. This differs from T. biebersteiniana by sterility; triploid karyotype; bigger flowers often of a pink-violet color; wider leaves, especially in vegetative specimens; and higher generative stems. It is distributed along the tributaries of the Belaya River in the western slope of the southern Urals (Fig. 1). Presently, the areal of $T$. riparia is not intercrossed with other tulip species. Moreover, crossbreeding is hardly possible because of its almost complete sterility. Areals of the other three species are partially intercrossed. Populations may be formed in places where their contacts mixed. We observed these populations of $T$. patens and T. scythica [6] in the outskirts of the railway station Guberlya in the Orenburg region.

Apparently, there are no considerable reproductive barriers between closely related species of tulips. This suggestion is supported by the observation of mixed populations and experiments with crossbreeding of $T$. scythica and T. quercetorum (T. biebersteiniana) in which normal fruits and seeds were obtained [9].

Therefore, it is quite obvious that T. biebersteiniana tulips are represented by a complicated genetic complex. However, the level of hybridization within this complex, as well as the contribution of genetic material of each of the species, remains unclear. The present research was aimed at studying genetic processes in populations of four closely related species of tulips using the method of amplified fragments length polymorphism (AFLP). The advantage of this method is that it allows one to simultaneously analyze a large 
Table 1. Characteristics of populations of four species of tulips

\begin{tabular}{|c|c|c|c|c|c|}
\hline Location & \multicolumn{2}{|c|}{ Population } & Latitude & Longitude & $\begin{array}{c}\text { Number } \\
\text { of chromosomes }(2 n)\end{array}$ \\
\hline \multicolumn{6}{|c|}{ Tulipa biebersteiniana } \\
\hline Volgograd region, Sredneakhtubinskii district & Akhtuba & AHT & $48^{\circ} 71^{\prime}$ & $44^{\circ} 83^{\prime}$ & 24 \\
\hline Volgograd region, Kamyshinskii district & Shcherbakovka & CHER & $50^{\circ} 51^{\prime}$ & $45^{\circ} 72^{\prime}$ & 24 \\
\hline Orenburg region, Gaiskii district & Khalilovo & HAL-b & $51^{\circ} 36^{\prime}$ & $58^{\circ} 07^{\prime}$ & 24,36 \\
\hline Orenburg region, Novotroitsk, Gorodskoi district & Guberlya & GUB & $51^{\circ} 28^{\prime}$ & $58^{\circ} 18^{\prime}$ & 24 \\
\hline Chelyabinsk region, Kizilskii district & Kizil'skoe & KIZ & $52^{\circ} 67^{\prime}$ & $58^{\circ} 97^{\prime}$ & 24 \\
\hline Kurgan region, Tselinny district & Ust'-Uiskoe & UST & $54^{\circ} 28^{\prime}$ & $63^{\circ} 94^{\prime}$ & 24 \\
\hline \multicolumn{6}{|c|}{ Tulipa patens } \\
\hline Orenburg region, Gaiskii district & Khalilovo & HAL-p & $51^{\circ} 36^{\prime}$ & $58^{\circ} 07^{\prime}$ & 24 \\
\hline Orenburg region, Kvarkenskii district & Sunduk & SUUN & $52^{\circ} 13^{\prime}$ & $59^{\circ} 76^{\prime}$ & 24 \\
\hline \multicolumn{6}{|c|}{ Tulipa riparia } \\
\hline Chelyabinsk region, Ashinskii district & Kuryak & KUR & $54^{\circ} 96^{\prime}$ & $57^{\circ} 67^{\prime}$ & 36 \\
\hline Chelyabinsk region, Ashinskii district & Sim & SIM & $55^{\circ} 05^{\prime}$ & $57^{\circ} 41^{\prime}$ & 36 \\
\hline Republic of Bashkortostan, Meleuzovskii district & Smakovo & SMAK & $53^{\circ} 05^{\prime}$ & $56^{\circ} 08^{\prime}$ & 36 \\
\hline \multicolumn{6}{|c|}{ Tulipa scythica } \\
\hline Volgograd region, Pallasovskii district & Bulukhta & BUL & $49^{\circ} 32^{\prime}$ & $46^{\circ} 01^{\prime}$ & 24 \\
\hline Orenburg region, Kuvandykskii district & Karagai-Pokrovka & KAR & $51^{\circ} 64^{\prime}$ & $57^{\circ} 89^{\prime}$ & 24 \\
\hline
\end{tabular}

number of unlinked loci. It also does not require preliminary knowledge about the DNA sequence. These dominant markers, which are evenly distributed all over the nuclear genome, were formerly used successfully in population genetic studies of Liliaceae and related families [10-13]. Population genetic studies of wild tulips using AFLP analysis have been conducted for the first time. Previously, this method was used for cultivated breeds $[14,15]$. Because traditional systematics is mostly based on morphological traits, we also carried out a morphologic analysis of populations of the studied species.

\section{MATERIALS AND METHODS}

Material for morphologic and genetic analysis was collected from natural populations of tulips of the Volgograd, Kurgansk, Orenburg, and Chelyabinsk regions and the Republic of Bashkortostan in 2006-2009 (Table 1). The number of chromosomes in plants of each population were previously estimated [16].

\section{Analysis of Morphological Traits}

Seven qualitative and two quantitative traits of generative plants have been studied. These traits included the stem height, number of leaves, number of flowers, length and width of the lower leaf, length and width of the second leaf and the type of ontomorphogenesis as follows:

1. the substituting bulb is nearly formed and there are no bulb chains capable of vegetative reproduction;

2. there are bulb chains, but they are incapable of vegetative reproduction (perianth color (1) yellow; (2) pink. A statistical analysis of quantitative data was performed with Statistica 6.0. The matrix composed based on qualitative and quantitative traits were analyzed using the method of principal coordinates using the PAST program [17]. The Hover distance was used because the analysis included both quantitative and qualitative traits.

\section{DNA Isolation and AFLP Analysis}

The genetic analysis (AFLP) involved 81 plants. The samples were collected taking into account the clonal structure of populations of T. riparia and T. biebersteiniana [18]. The number of plants varied from four to eight per population.

The genomic DNA was isolated by the CTAB method [19] from frozen $\left(-70^{\circ} \mathrm{C}\right)$ plant material (leaves and bulbs). AFLP analysis was carried out according to the standard-type protocol [20] with the modifications described in [21] using a 3130 Genetic Analyzer automatic sequenator (Applied Biosystems, United States) with fluorescently labeled EcoRI primers. In order to select an appropriate combination of 
selective primers, 12 pairs of the primers were tested. Three combinations with clear amplification profile and optimal number of fragments (EcoRI AGC ${ }^{\text {Ned }}+$ Mse CCGC, EcoRI ACTFam + Mse CCAC, EcoRI $\mathrm{ACG}^{\mathrm{Joi}}+$ Mse CCGC) were selected for further analysis. Fluorescently labeled products of each selective PCRs were linked to the molecular weight standard GeneScan ROX ${ }^{\mathrm{TM}} 500$ (Applied Biosystems, United States) prior to loading into the sequenator. The obtained amplification profiles (chromatograms) were analyzed using the GeneMapper ${ }^{\circledR}$ ver. 4.0 program (Applied Biosystems, United States). The founded lengths of the obtained fragments were verified manually. Only loci that demonstrated monosemantic interpretation were accepted for analysis. Monomorphous loci were not accepted. AFLP-typing of the fragments was represented as a matrix of either presence or absence with 1 or 0 coding, respectively.

\section{Data Analysis}

The parameters of intrapopulation variability were as follows: the percentage of polymorphous loci $(P)$, unbiased expected heterozygosity $\left(U H_{\mathrm{e}}\right)$, and Nei's genetic distances $(D)$ [22] calculated based on the allele frequencies of AFLP loci. The parameters were analyzed using the GENEALEX ver. 6 program taking into account the Hardy-Weinberg equilibrium. Genetic differentiation within and between populations, as well as between the Tulipa species, were assessed by analyzing molecular dispersion (AMOVA). The gene flow was calculated as follows: $N_{m}=0.25(1-$ $\left.F_{\mathrm{ST}}\right) / F_{\mathrm{ST}}$. The ordination or distribution of the studied samples in multidimensional space was estimated using the GENEALEX program with the method of principal coordinates based on genetic distances. An alternative analysis of the population structure and assessment of the probability of hybrid nature of species were carried out using the Bayes' algorithm based on the Hardy-Weinberg equilibrium model in the STRUCTURE 2.2 program [24, 25]. This approach allows one to estimate the probability of dividing specimens into a certain number of groups $K$. The optimal number of groups $K$ is the number at which the logarithm of probability achieves a plateau. The algorithm was repeated five times for each of the $K$ values, which varied from two to six. The admixture model was used, which takes into account the possible mixed origin of populations based on the independent frequencies of alleles between the clusters. The analysis was carried out in 1 million iterations. The burn-in point of the Markov chain was preliminarily chosen in 100000 iterations.

\section{RESULTS \\ Morphological Analysis}

The four studied species of tulips demonstrated a significant difference by all qualitative traits except the number of flowers per specimen (Table 2). The maximal values of the generative stem height and the size of leaves were observed for T. riparia. Minimal values of these parameters were observed in T. scythica and $T$. patens. Two populations of $T$. scythica differed considerably from each other by their height, number of flowers, and the length and width of leaves. Plants of the BUL population were characterized by higher generative stem and longer leaves, whereas the widths of leaves were significantly smaller than in the KAR population. Plants $T$. biebersteiniana from different populations differed from one another by the generative stem height and width of leaves. Minimal values of these traits were found in the HAL and GUB populations, while maximal values were observed in the CHER, AHT, and KIZ populations.

Typically, the tulips $T$. biebersteiniana differ from one another by a single flower on the generative stem. In 12 out of 13 populations studied, plants with only singular flowers were observed. The exception was BUL populations, in which plants with two and even three flowers were observed.

The average number of leaves in populations of T. patens and T. biebersteiniana was 2.07 and 2.03, respectively. Only few specimens had three leaves. Almost one-third of T. scythica plants and almost half of $T$. riparia plants had three leaves.

If based on quantitative traits alone, principal component analysis could not divide the sample into overlapping classes. However, an analysis carried out by both quantitative and qualitative traits using the Hover distances allowed us to divide the samples into overlapping classes (Fig. 2). The first three principal coordinates describe $32.3 \%, 18.0 \%$ and $11.1 \%$ of the total variety respectively. Samples were quite clearly grouped by species based on qualitative traits (Fig. 2). T. scythica is characterized by the 2nd type of ontomorphogenesis (bulb chain) and yellow flowers. $T$. patens is characterized by the same type of ontomorphogenesis, but pink flowers. The $T$. riparia was shown to have different tints of pink-violet and yellow flowers and the first type of ontomorphogenesis. The $T$. biebersteiniana is characterized by the same type of ontomorphogenesis, but the color of flowers is yellow in all populations besides KIZ. Plants T. riparia with yellow flowers are grouped with $T$. biebersteiniana, while several $T$. biebersteiniana plants from the KIZ population, which have pink flowers, are grouped with T. riparia.

\section{AFLP Analysis}

The use of three combinations of primers revealed 87 loci, according to which the studied specimens were genotyped. The number of polymorphous loci for each of the three combinations of primer pairs EcoRI $\mathrm{AGC}^{\mathrm{Ned}}+$ Mse CCGC, EcoRI ACT ${ }^{\mathrm{Fam}}+$ Mse CCAC, EcoRI $\mathrm{ACG}^{\mathrm{Joi}}+$ Mse CCGC was 32, 17, and 38 respectively. 
Table 2. Quantitative morphological traits of the four species of tulips: mean value \pm standard deviation

\begin{tabular}{l|c|c|c|c|c|c|c|c}
\hline Population & $\begin{array}{c}\text { Sample } \\
\text { size }\end{array}$ & $\begin{array}{c}\text { Height genera- } \\
\text { tive stem }\end{array}$ & $\begin{array}{c}\text { Number } \\
\text { of leaves } \\
\text { per specimen }\end{array}$ & $\begin{array}{c}\text { Number } \\
\text { of flowers } \\
\text { per specimen }\end{array}$ & $\begin{array}{c}\text { Lower } \\
\text { leaf length, } \\
\mathrm{cm}\end{array}$ & $\begin{array}{c}\text { Lower } \\
\text { leaf width, cm }\end{array}$ & $\begin{array}{c}\text { Second } \\
\text { leaf length, } \\
\mathrm{cm}\end{array}$ & $\begin{array}{c}\text { Second } \\
\text { leaf width, cm }\end{array}$ \\
\hline HAL-b & 43 & $26.86 \pm 6.53$ & $2.05 \pm 0.21$ & $1.00 \pm 0.00$ & $12.93 \pm 4.17$ & $0.99 \pm 0.36$ & $9.94 \pm 3.87$ & $0.73 \pm 0.29$ \\
\hline GUB & 18 & $27.46 \pm 5.42$ & $2.00 \pm 0.00$ & $1.00 \pm 0.00$ & $12.02 \pm 2.72$ & $0.89 \pm 0.16$ & $9.19 \pm 2.36$ & $0.62 \pm 0.15$ \\
\hline CHER & 20 & $32.10 \pm 4.20$ & $2.00 \pm 0.00$ & $1.00 \pm 0.00$ & $14.19 \pm 1.99$ & $1.29 \pm 0.22$ & $11.07 \pm 1.89$ & $0.88 \pm 0.20$ \\
\hline AHT & 14 & $31.02 \pm 8.34$ & $2.00 \pm 0.00$ & $1.00 \pm 0.00$ & $15.75 \pm 3.88$ & $1.15 \pm 0.33$ & $12.88 \pm 3.49$ & $0.91 \pm 0.28$ \\
\hline KIZ & 24 & $33.02 \pm 5.59$ & $2.04 \pm 0.20$ & $1.00 \pm 0.00$ & $15.69 \pm 3.12$ & $1.17 \pm 0.27$ & $12.69 \pm 2.95$ & $0.92 \pm 0.26$ \\
\hline $\begin{array}{l}\text { T. bieber- } \\
\text { steiniana }\end{array}$ & 119 & $29.48 \pm 6.70$ & $2.03 \pm 0.16$ & $1.00 \pm 0.00$ & $13.84 \pm 3.70$ & $1.08 \pm 0.32$ & $10.89 \pm 3.45$ & $0.79 \pm 0.28$ \\
\hline BUL & 34 & $25.57 \pm 4.14$ & $2.32 \pm 0.47$ & $1.18 \pm 0.45$ & $12.92 \pm 2.80$ & $0.58 \pm 0.19$ & $10.25 \pm 2.75$ & $0.48 \pm 0.20$ \\
\hline KAR & 22 & $20.76 \pm 3.35$ & $2.27 \pm 0.45$ & $1.00 \pm 0.00$ & $8.89 \pm 1.99$ & $1.29 \pm 0.21$ & $7.31 \pm 1.85$ & $0.89 \pm 0.20$ \\
\hline T. scythica & 56 & $23.68 \pm 4.51$ & $2.30 \pm 0.46$ & $1.11 \pm 0.36$ & $11.31 \pm 3.19$ & $0.86 \pm 0.40$ & $9.09 \pm 2.83$ & $0.64 \pm 0.29$ \\
\hline $\begin{array}{l}\text { T. patens, } \\
\text { HAL-p }\end{array}$ & 73 & $18.84 \pm 4.42$ & $2.07 \pm 0.25$ & $1.00 \pm 0.00$ & $9.33 \pm 1.22$ & $0.83 \pm 0.15$ & $7.77 \pm 1.20$ & $0.56 \pm 0.11$ \\
\hline $\begin{array}{l}\text { T. riparia } \\
\text { KUR }\end{array}$ & 38 & $39.02 \pm 5.90$ & $2.45 \pm 0.50$ & $1.00 \pm 0.00$ & $16.59 \pm 4.42$ & $1.51 \pm 0.39$ & $13.14 \pm 3.79$ & $1.05 \pm 0.24$ \\
\hline
\end{tabular}

Note: Differences among the species by all traits, except the number of flowers are confident at $p<0.05$.

Only 8 out of 87 loci were found in all four species of tulips with frequencies in the range of $5-100 \%$ (taking into account that all monomorphous loci were excluded from the analysis). We found 38 unique loci that were specific to only one of the four species. These included 11 loci specific for T. biebersteiniana and
T. patens, and eight loci of T. riparia and T. scythica. The number of common loci that were shared between two species only was ten for T. riparia and T. biebersteiniana, four for $T$. riparia and $T$. scythica, three for $T$. riparia and $T$. patens, two loci for the pairs of $T$. scythica with $T$. patens and T. biebersteiniana, and

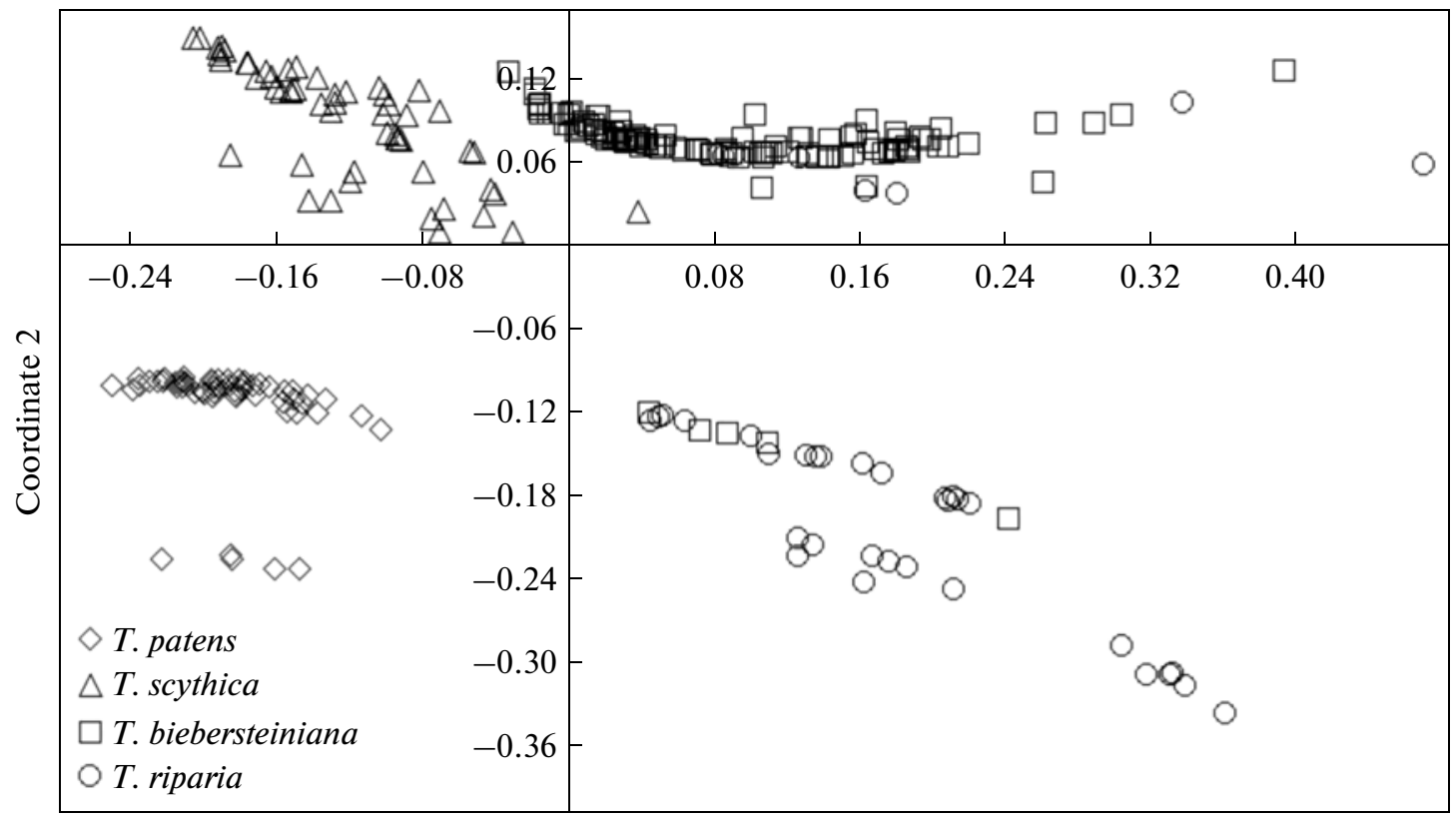

Coordinate 1

Fig. 2. Data of principal coordinate analysis for nine morphological traits. 


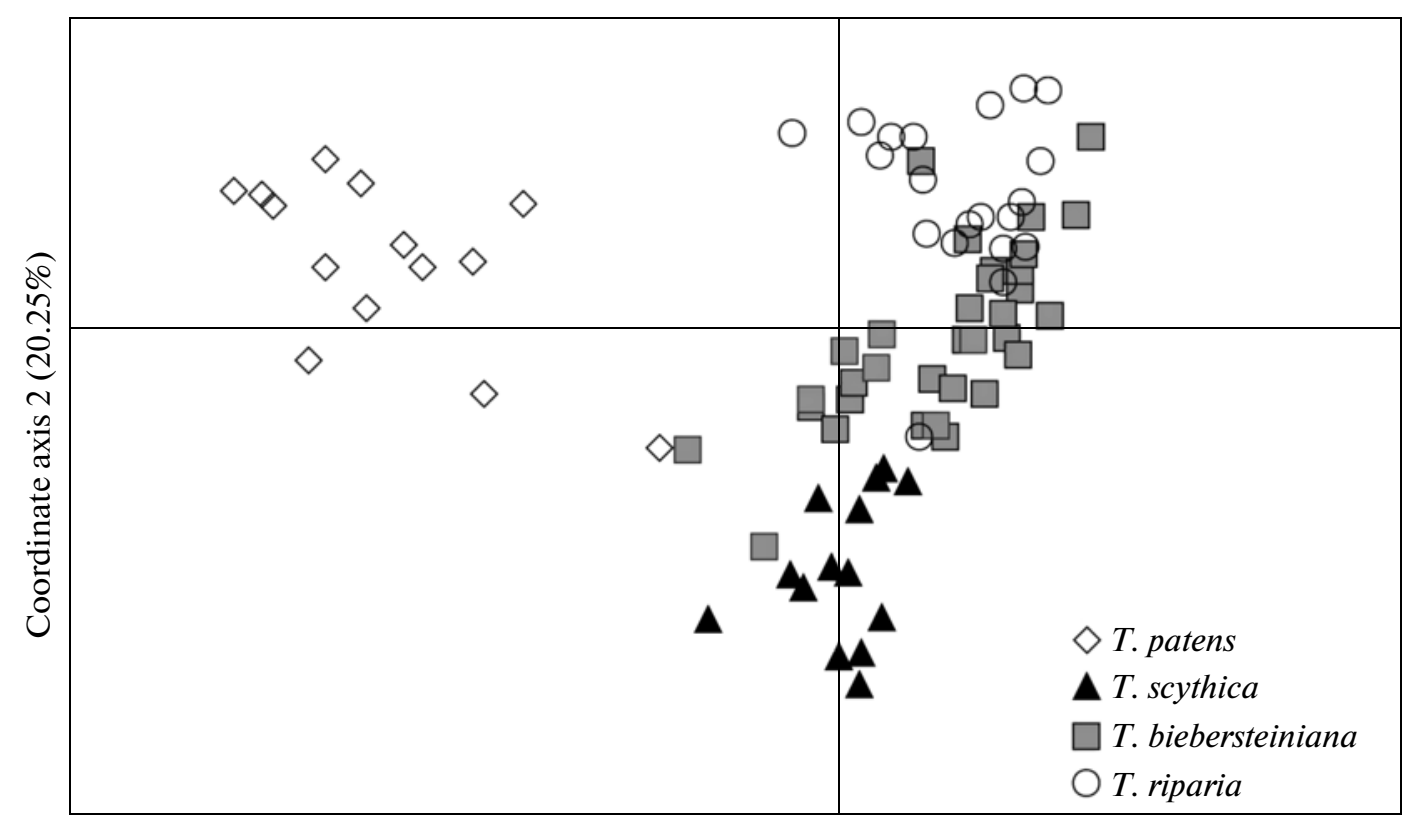

Coordinate axis $1(38.09 \%)$

Fig. 3. Data of principal coordinate analysis for 87 AFLP loci.

only one locus for the pair of T. patens and T. biebersteiniana.

The indicators of intrapopulation variability were shown to vary between the species. For T. biebersteiniana, the percentage of polymorphous loci $(P)$ was $20.41 \%$, for $T$. patens, it was $26.97 \%$; and, for $T$. scythica and T. riparia, it was $27.53 \%$ and $27.72, \%$ respectively. The average values of unbiased expected heterozygosity $\left(U H_{\mathrm{e}}\right)$ were $0.075,0.082,0.086$, and 0.096 for $T$. biebersteiniana, T. riparia, T. scythica, and T. patens, respectively (Table 3 ).

The AMOVA analysis showed that the variability between the four studied species of tulips was $23 \%$ (Table 4). The total intrapopulation dispersion was $56 \%$. The highest intraspecies differentiation was observed for T. biebersteiniana (33\%). Lower values were obtained for T. scythica- $30 \%$ and T. patens$27 \%$. The lowest differentiation was observed for T. riparia-13\%.

The highest values of Nei's distances $(D)$ were observed for $T$. patens with respect to $T$. riparia and T. biebersteiniana ( $D=0.067$ and 0.062 respectively) (Table 5). Pairs of T. biebersteiniana $(D=0.006)$ with T. riparia and T. scythica $(D=0.014)$ were found to be closely genetically related to one another.

Data form an AFLP analysis of 87 loci using the method of principal coordinates are presented in Fig. 3. The first three main coordinates describe $38.09,20.25$, and $12.55 \%$ of the total dispersion of traits. The results of grouping were different from those obtained in an analysis of morphological traits (Fig. 2). A special, clearly identifiable group was formed by specimens from two populations of $T$. patens (Fig. 3). Three other species, T. scythica, T. biebersteiniana, and T. riparia, formed a diffuse nonhomogeneous group. Specimens of $T$. scythica were shown to occupy a slightly detached position with respect to this group. Groups that correspond to T. biebersteiniana and T. riparia were shown to partially overlap.

The Bayes analysis by the STRUCTURE 2.2 program, which uses the admixture model, provided the maximal value of the logarithm of inverse probability for four groups in all iterations $(K=4)$. This means that the sample may be divided in four genetic clusters with maximal probability (Fig. 4). Not all the samples may be referred to one of the four species studied with high inverse probability. Some of them were identified by the program as ones with mixed genetic nature. At the same time $T$. biebersteiniana demonstrated a polymorphism. Its samples were conditionally divided in two groups, one of which is related to the uniform $T$. riparia, and the other to some samples of $T$. scythica. The pure group was formed by samples of $T$. patens and T. scythica.

\section{DISCUSSION}

\section{Genetic Polymorphism}

All populations of tulips demonstrated a low level of polymorphism, not only by the number of polymorphous AFLP loci, but also by heterozygosity. The level of genetic variability and differentiation of populations are closely connected with the type of reproduction, crossbreeding system, and characteristics of seed distribution [26]. This may be due to several factors. 
Table 3. Indicators of genetic diversity by 87 AFLP loci in tulip species T. biebersteiniana, T. riparia, T. scythica, and T. patens

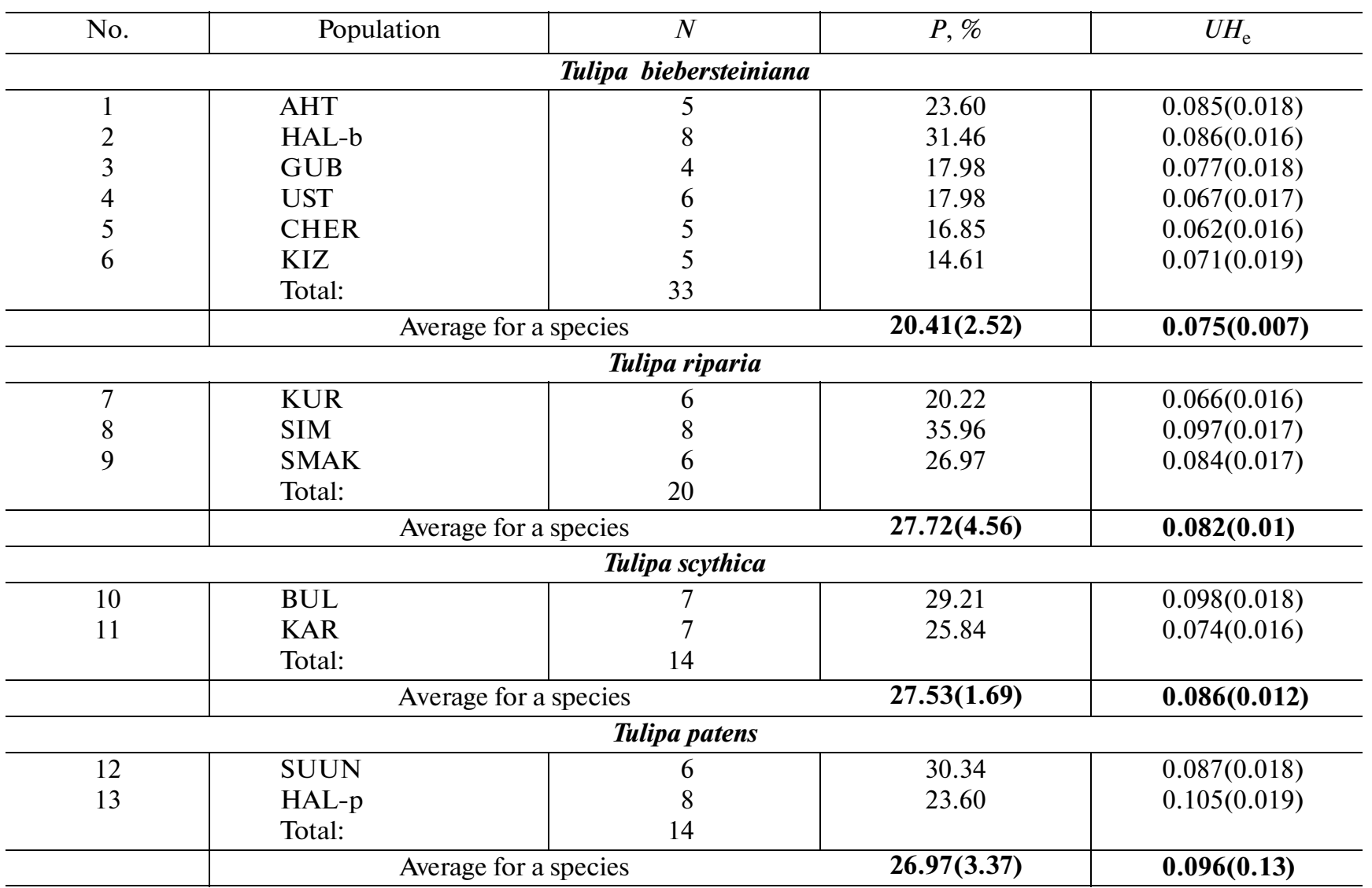

Note: $N$ is sample size; $P$ is percentage of polymorphous loci; $U H_{\mathrm{e}}$ is unbiased expected heterozygosity. Standard errors are given in brackets.

Table 4. Data of hierarchical dispersion analysis AMOVA by the allele frequences of AFLP loci

\begin{tabular}{|c|c|c|c|c|c|}
\hline Variability source & d.f. & $\begin{array}{l}\text { Variability } \\
\text { component }\end{array}$ & $\begin{array}{l}\text { Variability } \\
\text { percentage }\end{array}$ & $F$ statistics & $N_{m}$ \\
\hline Between groups (species) & 3 & 1.992 & 23 & $F_{\mathrm{CT}}=0.235^{*}$ & \\
\hline Between populations within the group & 9 & 1.728 & 20 & $F_{\mathrm{ST}}=0.439 *$ & 0.319 \\
\hline Within populations & 68 & 4.76 & 56 & $F_{\mathrm{SC}}=0.266^{*}$ & \\
\hline Total: & 80 & 8.48 & 100 & & \\
\hline \multicolumn{6}{|l|}{ Between populations within the species: } \\
\hline T. biebersteiniana & 5 & 2.092 & 33 & $F_{\mathrm{ST}}=0.332 *$ & 0.503 \\
\hline T. riparia & 2 & 0.787 & 13 & $F_{\mathrm{ST}}=0.133^{*}$ & 0.750 \\
\hline T. scythica & 1 & 2.082 & 30 & $F_{\mathrm{ST}}=0.297 *$ & 0.592 \\
\hline T. patens & 1 & 1.921 & 27 & $F_{\mathrm{ST}}=0.266^{*}$ & 0.690 \\
\hline
\end{tabular}

Note: * Is $P \leq 0.01$.

Table 5. Nei's genetic distances [22] estimated based on allele frequencies of AFLP loci between the studied species of tulips

\begin{tabular}{c|c|c|c|l}
\hline T. biebersteiniana & T. riparia & T. scythica & T. patens & \\
\hline- & & & & T. biebersteiniana \\
0.006 & - & - & & T. riparia \\
0.014 & 0.025 & 0.064 & - & T. scythica \\
0.062 & 0.067 & T. patens \\
\hline
\end{tabular}




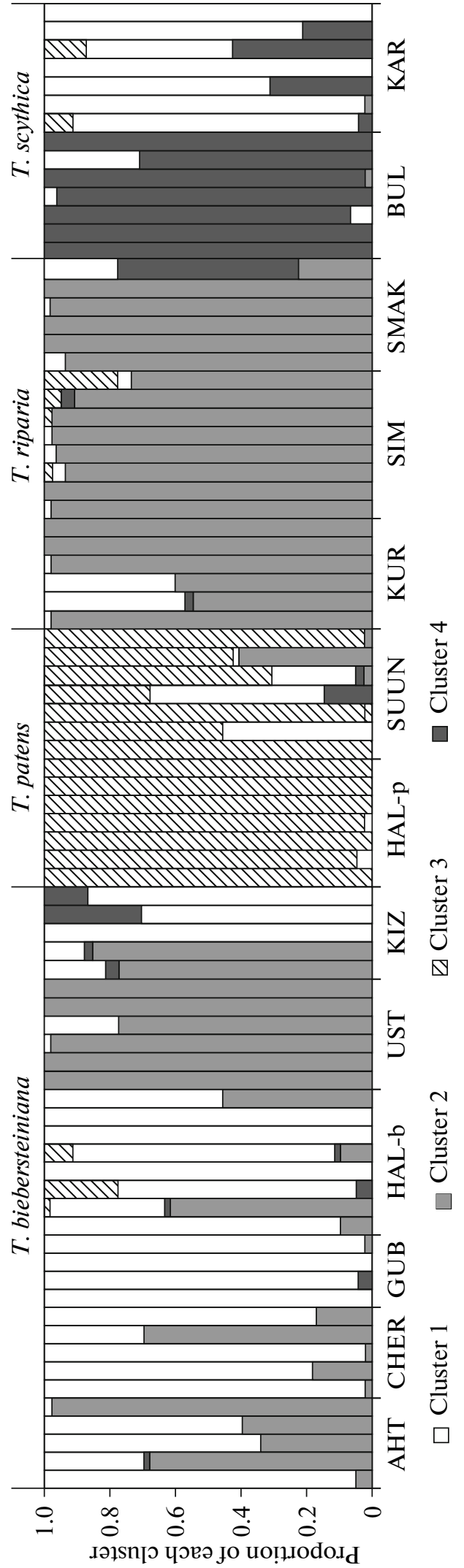

Fig. 4. Probability of referring of 81 specimens of Tulipa genus to one of the four clusters according to the data of AFLP analysis.
1. T. riparia and T. biebersteiniana are capable of vegetative reproduction that leads to the formation of clones. Inside the clones, no effective pollination and fertilization occurs due to self-incompatibility. In $T$. riparia, we observed the pollen tube growth along the snout rather than inside the pistil. We also observed the formation of loops and swellings [27], which was considered to be evidence of disorder in the pollination system.

2. T. riparia is a triploid (Table 2) and its seminal reproduction is repressed. T. biebersteiniana can easily be transformed onto the triploid level under conditions unfavorable for seminal reproduction. This phenomenon was observed not only in the HAL-b population, but also in other populations not included in the present study.

3. The decrease in polymorphism may be caused by ecological factors. In the studied AHT, CHER, UST, and $\mathrm{KIZ}$ populations, the T. biebersteiniana is grown either under the forest canopy or in a bushy area, where pollination is complicated. Moreover, the KIZ population, which is characterized by the minimal number of polymorphous loci, undergoes strong anthropogenic influence.

4. Apparently, some populations of the studied species contain mutations connected with the female reproduction system and manifest as the sterilization of ovules and underdevelopment or total absence snout. Indeed, the KIZ population was found to contain $45.8 \%$ of sterile ovules and the BUL population was $37.1 \%$. In some populations of T. patens, half of the specimens had sterile ovaries (unpublished data).

\section{Genetic Differentiation of Populations}

The level of differentiation of tulip populations by AFLP markers was close to that obtained for Liliaceae and related families $[10,11]$ with the average values obtained for allogamous $\left(F_{\mathrm{ST}}=0.28\right)$ and long-living herbaceous plants $\left(F_{\mathrm{ST}}=0.25\right)$ by the RAPD-markers [28]. It was found out that there is a gene flow $\left(N_{m}\right)$ between populations within the species that varied from 0.5 to 0.75 specimens per generation. In vegetatively mobile $T$. riparia and $T$. biebersteiniana gene transferring is provided not only by transferring $\mathrm{f}$ pollen and seeds, but also daughter bulbs. This process is especially important for the genetic structure of populations of $T$. riparia that grow alongside rivers. During spring floods, its bulbs are transferred by water [18]. Apparently, this causes the lowest differentiation of populations of $T$. riparia $\left(F_{\mathrm{ST}}=0.13\right)$.

Nei's distances calculated based on allele frequencies of AFLP loci (Table 5), which demonstrated close relations among all four species; the most remote species is $T$. patens. Similar results were obtained by the method of principal coordinates (Fig. 3) and by calculations carried out with the STRUCTURE 2.2 program (Fig. 4). T. patens is considered to be morphologically and genetically expressed species, which is 
equally remote from the other three species. Hence, the suggestion of $[6,8]$ about the relation and even identity of T. patens and T. scythica was not confirmed. Although T. patens and T. biebersteiniana grow in the outskirts of Khalilovo together, the HAL-p population of $T$. patens was found to be genetically pure. These species are separated ectopically. $T$. patens grows at the tops of hills, whereas T. biebersteiniana occupies lowlands between hills and high-water beds. Moreover, T. patens begin to blossom 1-1.5 weeks earlier than T. biebersteiniana. Taking into account the expressive protandry of tulips, it might be suggested that, in the HAL population, the one-way transfer of genetic material from $T$. biebersteiniana to $T$. patens takes place. However, this is not true (Fig. 4). Conversely, some specimens of T. biebersteiniana of this populations carry alleles of $T$. patens. The second population of $T$. patens (SUUN) is less genetically homogenous.

T. riparia was found to be quite homogenous both genetically and morphologically (Figs. 2-4), though some of its specimens carry alleles of other species. Populations UST and some specimens of the KIZ population of T. biebersteiniana belong to the same genetic group. The AHT population also demonstrated considerable admixture of the second cluster alleles. This is partially consistent with morphological data, according to which plants from the AHT and KIZ populations possess higher stem and wider leaves. Interestingly, different molecular approaches, such as AFLP, ITS, and ISSR markers [29], demonstrated close relationships between $T$. biebersteiniana and $T$. riparia, as well as suggest the autopolyploidy of the latter. Conversely, morphological study of chromosomes as well as their differential staining [16] confirmed the hypothesis of hybrid origins of $T$. riparia and the presence of allopolyploidy.

Populations GUB and HAL-b of T. biebersteiniana definitely refer to the first cluster. However, the first population is genetically pure, while the second contains alleles of other species, including T. patens. Therefore, according to data, the species $T$. biebersteiniana is represented by a genetically nonhomogenous group. Northeastern KIZ and especially UST populations are close to T. riparia by AFLP alleles. This apparently suggests that the origination of $T$. riparia is connected with the very northeastern populations of T. biebersteiniana.

It was found out that T. scythica is also represented by nonhomogenous group. The BUL population forms the fourth cluster. The KAR population, together with most populations $T$. biebersteiniana, refers to the first cluster and carries only few alleles of T. scythica. These data are consistent with morphological ones. Multiflowered specimens were found in the BUL population. This trait was not observed in other populations. Plants of the KAR population morphologically occupy intermediate position between T. scythica and T. biebersteiniana. They are characterized by the type- 2 ontogenesis (bulb chain) and low stem height, similar to T. scythica. On the other hand, they are close to $T$. biebersteiniana in the width of leaves.

The use of the STRUCTURE 2.2 program showed that the differentiation of tulips based on morphological traits is not always consistent with genetic groups identified in our study. This may be due to hybridization between closely related species and one-way gene transfer. The use of AFLP analysis was shown to be quite effective when studying of genetic processes in populations of tulips and solving problems that occur in morphological systematics of closely related species. To obtain more precise data, it is necessary to increase the studied samples and pay special attention to hybrid populations.

\section{ACKNOWLEDGMENTS}

The authors thank A.Yu. Belyaeva, G.Yu. Klinkova, M.I. Zherebtsova, O.E. Sushentsova and V.V. Kukarskikh for their kind help with material collection and M.S. Knyazeva for preparing Fig. 1.

This work was supported by the Russian Foundation for Basic Research, project no. 10-04-00989 and by the Federal Targeted Program, project no. 14.740.11.1032

\section{REFERENCES}

1. Stork, A., Tulipes sauvages et cultivees, Geneve: Conservatoire et jardin botanique, 1984.

2. Van Raamsdonk, L., Eikelboom, W., De Vries, T., and Straathof, P., The Systematics of the Genus Tulipa L., Proceedings of the 7th International Symposium on Flower Bulbs, Herzliya, Israel, 1996, no. 430 of Acta Hortic., Lilien-Kipnis, H., Halevy, A.H., and Borochov, A., Eds., Leuven, 1997, pp. 821-828.

3. Hall, A.D., The Genus Tulipa L., London: Royal Horticultural Society, 1940.

4. Govaerts, R., World Checklist Series, RBG Kew, UK: Genus Tulipa, 2008. http://apps.kew.org/wcsp/ qsearch.do

5. Zonneveld, B.J.M., The Systematic Value of Nuclear Genome Size for "All” Species of Tulipa L. (Liliaceae), Plant. Syst. Evol., 2009, vol. 281, pp. 217-245.

6. Knyazev, M.S., Kulikov, P.V., and Filippov, E.G., Tulips from Tulipa biebersteiniana Alliance (Liliaceae) at the South Urals, Bot. Zh., 2001, vol. 86, no. 3, pp. 109119.

7. Cherepanov, S.K., Sosudistye rasteniya Rossii i sopredel'nykh gosudarstv (Vascular Plants of Russia and Neighboring Countries), St. Petersburg: Mir i sem'ya, 1995.

8. Flora Nizhnego Povolzh'ya (Flora of the Low Povolzhye), Skvortsov, A.K., Ed., Moscow: KMK, 2006, vol. 1.

9. Sokolova, E.I. and Berezhnoi, M.V., Species Affiliation of Tulips from Tulipa biebersteiniana Alliance (Liliaceae) Inferred from Application of the Genetic Criterion of a Species, Sinteticheskaya teoriya evolyutsii: sos- 
toyanie, problemy, perspektivy (Synthetic Theory of Evolution: Current State, Problems, Perspectives), (Proc. Int. Sci. Conf. in Memoriam of 200th Anniversary of Charles Darvin and 150th Anniversary of the Book On the Origin of Species by Means of Natural Selection, or the Preservation of Favored Races in the Struggle for Life, Lugansk, 2009), Lugansk: Elton-2, 2009, pp. 81-83.

10. Zhang, D., Gao, L., and Yang, Y.-P., Genetic Diversity and Structure of a Traditional Chinese Medicinal Plant Species, Fritillaria cirrhosa (Liliaceae) in Southwest China and Implications for Its Conservation, Biochem. Syst. Ecol., 2010, vol. 38, pp. 236-242.

11. Qiao, Q., Zhang, C.Q., and Milne, R.I., Population Genetics and Breeding System of Tupistra pingbianensis (Liliaceae), a Naturally Rare Plant Endemic to SW China, J. Syst. Evol., 2010, vol. 48, no. 1, pp. 47-57.

12. Pfeiffer, T., Klahr, A., Heinrich, A., and Schnittler, M., Does Sex Make a Difference? Genetic Diversity and Spatial Genetic Structure in Two Co-Occurring Species of Gagea (Liliaceae) with Contrasting Reproductive Strategies, Plant Syst. Evol., 2011, vol. 292, pp. 189-201.

13. Kubota, S., Kameyama, Y., and Ohara, M., A Reconsideration of Relationships among Japanese Trillium Species Based on Karyology and AFLP Data, Plant Syst. Evol., 2006, vol. 261, pp. 129-137.

14. Maunde, M., Cowan, R.S., Stranc, P., and Fay, M.F., The Genetic Status and Conservation Management of Two Cultivated Bulb Species Extinct in the Wild: Tecophilaea cyanocrocus (Chile) and Tulipa sprengeri (Turkey), Conserv. Genet., 2001, vol. 2, pp. 193-201.

15. Bondrea, I., Pamfil, D., van Heusden, S., et al., AFLP as a Modern Technique for DNA Fingerprinting and Identification Tulipa Cultivars, Bull. USAMV-CN, 2007, pp. 63-64.

16. Kutlunina, N.A., Zherebtsova, M.I., and Kotseruba, V.V., Cytogenetic Study of Tulips, Section Eriostemones (Liliaceae) from the South Urals, Botanicheskie issledovaniya na Urale (Botanical Investigations in Urals), (Proc. Regional Sci. Conf. with Int. Participation, Perm'), Perm': Perm', 2009, pp. 213-215.

17. Hammer, O., Harper, D.A.T., and Ryan, P.D., PAST: Paleontological Statistics Software Package for Education and Data Analysis, Palaeontol. Electron., 2001, vol. 4, no. 1, p. 9. http://palaeo_electronica.org/ 2001_1/past/issue1_01.htm
18. Kutlunina, N.A. and Belyaev, A.Yu., Genotypic Diversity and Clone Structure in Populations of Two Closely Related Tulip Species at the South Urals, Vestn. Orenburg Gos. Univ., 2008, no. 2, pp. 93-98.

19. Devey, M.E., Bell, J.S., Smith, et al., A Genetic Linkage Map for Pinus radiate Based on RFLP, RAPD and Microsatellite Markers, Theor. Appl. Genet., 1996, vol. 92, pp. 673-679.

20. Vos, P., Hogers, R., Bleeker, M., et al., AFLP: A New Technique for DNA Fingerprinting, Nucleic Acids Res., 1995, vol. 23, pp. 4407-4414.

21. Samils, B., Lagercrantz, U., Lascoux, M., et al., Genetic Structure of Melampsora epitea Populations in Swedish Salix viminalis Plantations, Eur. J. Plant Pathol., 2001, vol. 107, pp. 399-409.

22. Nei, M., Estimation of Average Heterozygosity and Genetic Distance from a Small Number of Individuals, Genetics, 1978, vol. 83, pp. 583-590.

23. Peakall, R. and Smouse, P.E., GENALEX 6: Genetic Analysis in Excel. Population Genetic Software for Teaching and Research, Mol. Ecol. Notes, 2006, vol. 6 , pp. 288-295.

24. Pritchard, J.K., Stephens, M., and Donnelly, P., Inference of Population Structure Using Multilocus Genotype Data, Genetics, 2000, vol. 155, pp. 945-959.

25. Falush, D., Stephens, M., and Pritchard, J.K., Inference of Population Structure Using Multilocus Genotype Data: Dominant Markers and Null Allele, Mol. Ecol. Notes, 2007, vol. 7, no. 4, pp. 574-578.

26. Hamrick, J.L. and Godt, M.J., Allozyme Diversity in Plant Species, Plant Population Genetics, Breeding and Genetic Variation in Plants, Brown, A.H.D., Clegg, M.T., Kahler, A.L., and Weir, B.S., Eds., Sunderland: Sinauer Associates, 1989, pp. 43-63.

27. Zherebtsova, M.I. and Kutlunina, N.A., The Ratio of Vegetative and Seminal Reproduction among Populations of Tulips, Section Eriostemones, Embriologiya, genetika i biotekhnologiya (Proc. 3d Int. School Young Sci.), Saratov: Izd. Saratov Univ., 2009, pp. 46-49.

28. Nybom, H. and Bartish, I., Effects of Life History Traits and Sampling Strategies on Genetic Diversity Estimates Obtained with RAPD Markers in Plants, Persp. Plant Ecol. Evol. Syst., 2000, vol. 3, pp. 93-114.

29. Kutlunina, N.A., Zherebtsova, M.I., and Kotseruba, V.V., Molecular-Genetic Study of Tulips (Subgenus Eriostemones), Molecular Phylogenetics (Proc. 2nd, Moscow Int. Conf., Moscow, 2010), Moscow: Torus, 2010, pp. $47-48$. 